\title{
Tuning Porphyrin/DNA Supramolecular Assemblies by Competitive Binding
}

\author{
Luigi Monsù Scolaro, ${ }^{\mathrm{a}, \mathrm{b}}$ Andrea Romeo, ${ }^{\mathrm{a}, \mathrm{b}}$ Robert F. Pasternack. ${ }^{*}, \mathrm{c}$
}

\begin{abstract}
${ }^{a}$ Dipartimento di Chimica Inorganica, Chimica Analitica e Chimica Fisica, Università di Messina, Salita Sperone 31, 98166 Vill.S.Agata, Messina, Italy. ${ }^{b}$ INFM, Unità di Messina, Messina, Italy. ${ }^{c}$ Department of

Chemistry, Swarthmore College, Swarthmore, Pennsylvania 19081, USA.
\end{abstract}

\section{Supporting Information}

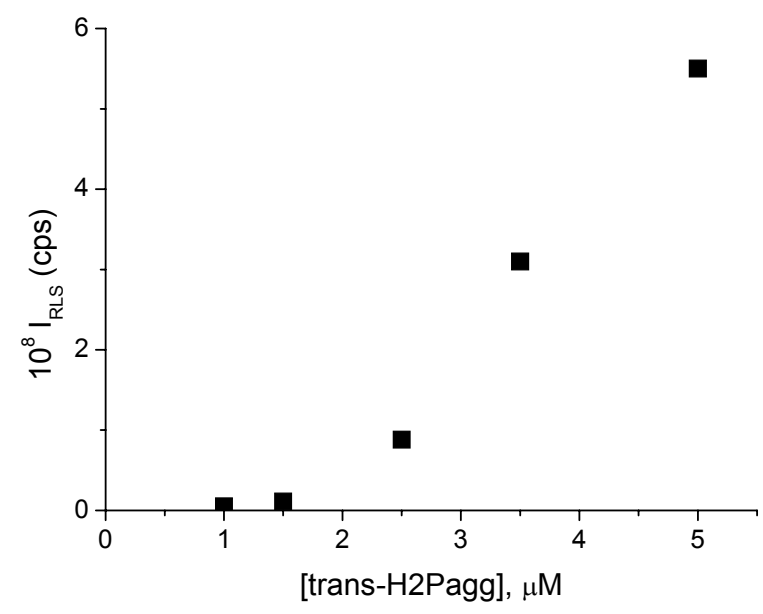

Figure SI1. Resonance light scattering intensity for $\mathrm{t}-\mathrm{H}_{2} \mathrm{Pagg} / \mathrm{DNA}$ supramolecular assemblies as a function of porphyrin concentration. (-) $\mathrm{t}_{-} \mathrm{H}_{2} \mathrm{Pagg}$ at $[\mathrm{DNA}]=25 \mu \mathrm{M},[\mathrm{NaCl}]=0.05 \mathrm{M}$ in $1 \mathrm{mM}$ phosphate buffer $\mathrm{pH} 6.7, \mathrm{~T}=298 \mathrm{~K}(\lambda=465 \mathrm{~nm})$. 
A
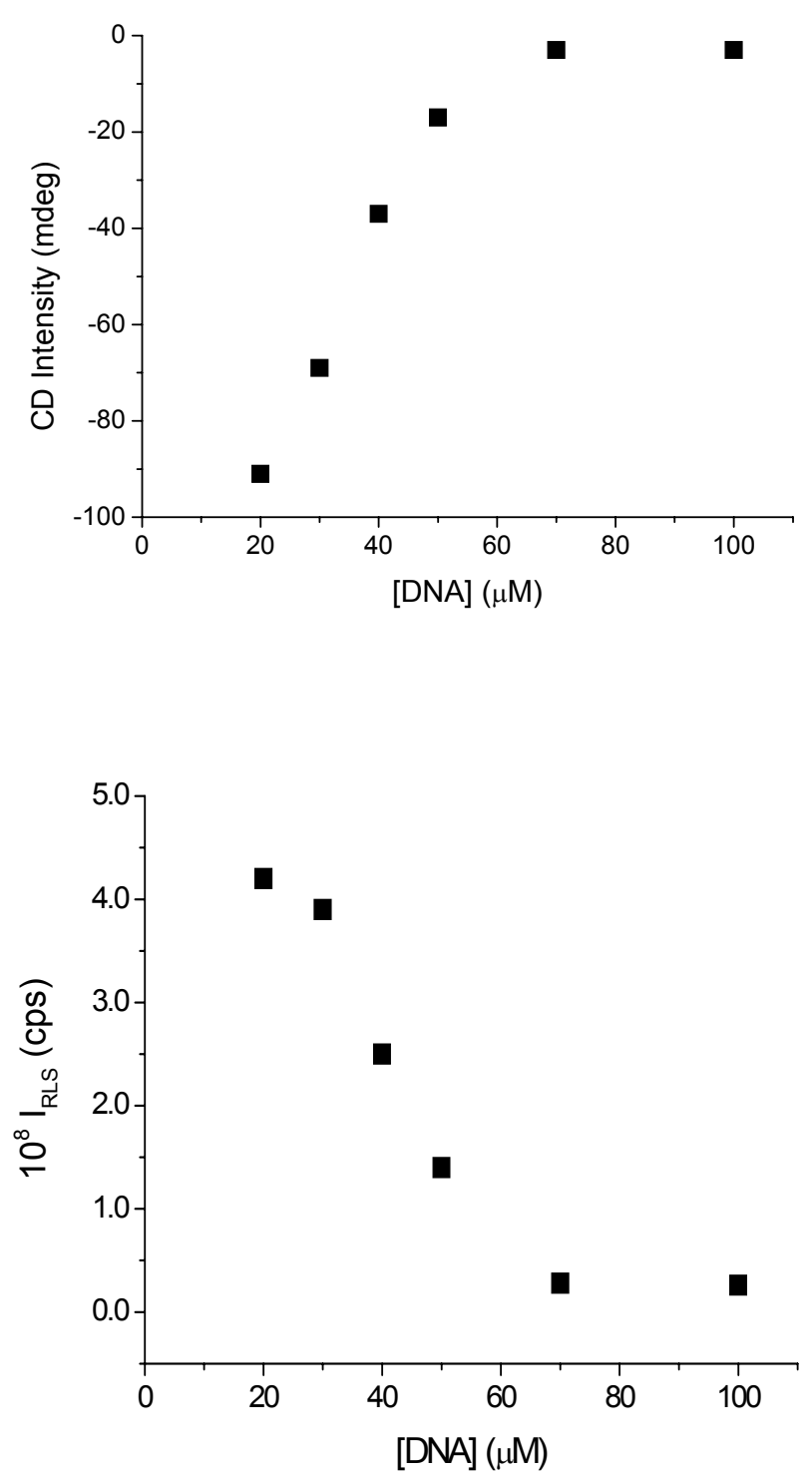

Figure SI2. Induced circular dichroism (A) and resonance light scattering (B) intensity for t$\mathrm{H}_{2} \mathrm{Pagg} / \mathrm{AuT}$ /DNA supramolecular assemblies as a function of DNA concentration. [t- $\left.\mathrm{H}_{2} \mathrm{Pagg}\right]=$ $3.5 \mu \mathrm{M},[$ AuT4] $=1.5 \mu \mathrm{M},[\mathrm{NaCl}]=0.05 \mathrm{M}$ in $1 \mathrm{mM}$ phosphate buffer $\mathrm{pH} 6.7$. 